\title{
Los dibujos de John Gilbert para el Quijote. Modelo iconográfico para la decoración de las lozas de la Real Fábrica de Sargadelos
}

\author{
Natalia Fraguas FernándeZ*
}

\begin{abstract}
Resumen
La Real Fábrica de Sargadelos (Cervo-Lugo), uno de los centros cerámicos de referencia en el panorama industrial del siglo XIX en España, introdujo en su tercera etapa (1845-1862) una nueva serie decorativa en la que el motivo principal reproducía, mediante la técnica de estampación, distintas escenas del Quijote. Considerada por muchos como una de las más interesantes de su producción, utilizaron como modelo iconográfico para su elaboración los dibujos que el pintor e ilustrador inglés John Gilbert (1817-1897) realizó para una edición londinense de la novela publicada por Charles Daly en 1842 .

Como ejemplo de esta variante se conservan en la actualidad un número de piezas que no supera las noventa entre colecciones particulares e instituciones públicas, destacando en el segundo caso el Museo de Pontevedra con diez ejemplares.
\end{abstract}

Palabras clave: Quijote; iconografía; loza; Sargadelos; John Forrester; Museo de Pontevedra; dibujo; grabado; John Gilbert; Robert Cruikshank.

Title: John Gilbert's Drawings for Don Quixote. Iconographic Model for the Decoration of Real Fábrica de Sargadelos Pottery

\footnotetext{
Abstract

The Real Fábrica de Sargadelos (Cervo-Lugo), one of the most relevant ceramic centres in the industrial panorama of the 19th century in Spain, introduced on its third stage (18451862) a new decorative serie whose main goal was reproducing, with stamping technique, different scenes of Don Quixote. The serie was considered by many as one of the most

* Museo de Pontevedra. natalia.fraguas@depo.es / ORCID iD: https://orcid.org/0000-00025970-3603.
} 
interesting of its production and used as an iconography model the drawings that the English painter and illustrator John Gilbert (1817-1897) made for a London edition of the novel published by Charles Daly in 1842 .

As an example of this variant, a number of pieces, which does not exceed ninety, are kept by private collections and public institutions, among which the Museo de Pontevedra stands out for its ten copies.

Keywords: Quixote; Iconography; Pottery; Sargadelos; John Forrester; Museo de Pontevedra; Drawing; Engraving; John Gilbert; Robert Cruikshank.

\section{Cómo citar este artículo / Citation}

Fraguas Fernández, Natalia. 2020. «Los dibujos de John Gilbert para el Quijote. Modelo iconográfico para la decoración de las lozas de la Real Fábrica de Sargadelos». Anales Cervantinos 52: 57-86, https://doi.org/10.3989/anacervantinos.2020.003.

\section{INTRODUCCIÓN}

En 1804 se fundaba en Sargadelos, parroquia del municipio de Cervo, en la provincia de Lugo, una fábrica de loza que bajo el mismo nombre de su emplazamiento acabaría convirtiéndose en uno de los centros cerámicos de referencia en el panorama industrial del siglo XIX en España y el más importante de los que hayan existido en Galicia.

Creada por iniciativa del hidalgo asturiano Antonio Raymundo Ibáñez (Meijide Pardo 1979), respondía a los deseos de expansión de unos negocios que tenían su origen más próximo en la ya asentada fábrica de fundición establecida desde 1791, año de su creación por Real Cédula, en el mismo recinto que ahora ocuparía la destinada a la producción de piezas cerámicas:

Las Fabricas se hallan sitas en la Feligresía de Sargadelos, en donde llaman Monte do Medio. El terreno que tenemos adquirido en aquel lugar compondrá mas de una legua y quarto de circunferencia dentro del qual se halla una Casa Principal de dos patios, con Capilla, Oficinas Correspondientes, huerta, y Jardines; La Fabrica de Municiones con Carboneras, Refineria, Ornos de Calzinaz ${ }^{\mathrm{n}}$; maquina llamada Bocarte, Tinglados, casas y ranchos paralos Operarios: Una hermosa Herrería, a caso la mejor de España, contodas sus oficinas; la casa de la Fabrica de Loza, compuesta de dos patios, Ornos y tinglados con el Molino correspondiente, y maquinas para romper el pedernal, y moler los barnizes: Yasi mismo dos Molinos arineros; un puente dedos arcos, y cinco prados regadíos de crecida extensión, afin de proporcionar forrage para el Ganado empleado enlas conducciones; y el resto del expresado terreno en toda su redondez lo tenemos plantado de pinos con el mejor suceso, excediendo en el dia de mas de seiscientos mil pies. 
En el intermedio de las obras hai hermosos caminos, adornados de Alamedas, que recrean y hermosean el Establecimiento, endonde tenemos elegido dos sitios; el uno para establecer una Fabrica de botellas y bidrios, y el otro para planificar una Casa Meson con Mercado semanal, tinglados y mas necesario para cuias obras nos hallamos actualmente acopiando maderas y materiales, afin de ejecutarlas conla brevedad posible'.

Un emplazamiento privilegiado en el que se encontraba, a pesar de su relativo aislamiento y difícil comunicación, todo lo necesario para el inicio de un proyecto empresarial cuyo objetivo principal no era otro que el poder competir con las manufacturas del mismo género que por entonces se importaban a la región, ofreciendo al público loza fina de calidad a imitación de la inglesa (la llamada «loza tipo Bristol» que entonces gozaba de gran difusión y aceptación en nuestro país) con modelos, formas, diseños y decoraciones novedosas y un acabado final aparente en el que a la utilidad se sumaba la elegancia y un precio de mercado asequible «p[ara] $\mathrm{q}[\mathrm{ue}]$ todo el mundo pueda adquirirla sin incomodarse $»^{2}$.

El reconocimiento oficial de la calidad de sus productos por parte de la Junta Suprema del Reino de Galicia ${ }^{3}$ y la inmediata comercialización de los mismos, ayudarían a que las cerámicas producidas -destinadas fundamentalmente a la clase burguesa- se diesen a conocer más allá de las tierras gallegas, contando ya en 1815 con distintos puntos de venta en la capital española en clara competencia con las lozas de importación ${ }^{4}$.

No obstante y a pesar del éxito inicial, el discurrir del establecimiento estará marcado en los años sucesivos por constantes altibajos de índole económico que llevarán al cierre del mismo en distintos periodos. El despegue de la factoría no llegará hasta 1845 en el que se inicia la que será su etapa de máximo esplendor. La firma de un arrendamiento entre la familia propietaria y una compañía solvente representada por el comerciante pontevedrés Ramón Francisco Piñeiro ${ }^{5}$ y sus socios Luis de la Riva Barros ${ }^{6}$, Antonio Casas y José

1. Descripción de las Fábricas de Sargadelos. Razón de los Títulos de su pertenencia. 1808. Archivo documental del Museo de Pontevedra, Archivo general 48-2.

2. Acto en el que José Ibañez solicita protección al Tribunal Supremo de la Nación para que lo exima de la ejecución por las deudas contraidas por su padre. 1814. Archivo documental del Museo de Pontevedra, Archivo general 48-4.

3. En 1810 se le envió un muestrario compuesto de 59 piezas, para el servicio de mesa y el aseo, «cuya loza es dela que acaba de trabajarse en dha Fabrica, y que dentro de un mes se pondrá deventa al Público; Asegurando que cadavez toma mejor el Baño, por haberse descubierto una tierra superior. En Factura delas Piezas de Loza que se remiten de la $\mathrm{R}^{1}$ Fabrica de Sargadelos, su Dueño $\mathrm{D}^{\mathrm{n}}$ Josef Ybañez, en el Barco de $\mathrm{D}^{\mathrm{n}}$ Ramón Farto, con destino al Sr Presidente y $\mathrm{S}^{\text {res }}$ dela Junta superior de este $\mathrm{R}^{\mathrm{no}}$ ». 1810. Archivo documental del Museo de Pontevedra, Archivo General 47-3.

4. Diario de Madrid, n. ${ }^{\circ} 126,6$ de mayo de 1815, p. 495.

5. Comerciante de Carril, localidad del municipio pontevedrés de Vilagarcía de Arousa, propietario de varios barcos mercantes y de pesca (Carmona Badía 1993, 26).

6. Luis de la Riva era hijo del mayorista compostelano Manuel de la Riva y Moreno, encargado de la comercialización desde los años veinte de la mayor parte de los potes de hierro que, por encargo, producía la fábrica de fundición de Sargadelos (Carmona Badía 1993, 24 y 26; Carmona Badía 2009, 22-48). 
María Múñiz ${ }^{7}$, permitirá el ansiado desarrollo empresarial. Con este objetivo se llevará a cabo -a partir de 1848 constituidos como una nueva compañía mercantil e industrial denominada Luis de la Riva y Compañía ${ }^{8}$ - una importante modernización técnica basada en el modo de hacer de las fábricas inglesas (Madoz 1849, 861-864) cuyo reconocimiento será realizado in situ por los comisionados de la empresa que viajarán desde Lugo con destino a Inglaterra (Neira de Mosquera 1851, 405-406). Esta misión permitirá, entre otros, la incorporación de nuevos operarios especializados -franceses, ingleses y alemanes- que trabajarán como horneros, tiradores, tornistas y en el estampado y pintura de la loza. Junto a ellos el que pasará a ser el nuevo director de la fábrica, el inglés Mr. Edwin Forrester Heath, nacido en 1817 en Burslem (Staffordshire) ${ }^{9}$, un lugar de referencia en la industria cerámica. Su contratación será uno de los mayores aciertos de la empresa consiguiendo, gracias a sus conocimientos y presumible experiencia, la introducción de las últimas novedades en técnicas decorativas -decoración mecánica- y también en la elaboración de pastas, de una calidad muy superior a las que se habían usado hasta ese momento.

Los clientes, que contarán con nuevos puntos de venta en la capital española, se encontrarán ahora con una gran variedad de formas y diseños además de un amplio abanico de motivos decorativos. De los hornos de la fábrica, entonces con una producción diaria de 104 hornadas de loza, saldrán -además de vajillas, juegos de café, té y chocolate- jarras, jarrones, piezas de escritorio, aseo y tocador, figuras decorativas y botes de farmacia. En ellas se aplicarán -de acuerdo con el «riguroso plan inglés» establecido y en los colores

7. Comerciante y banquero de Lugo respectivamente (Carmona Badía 1993, 26, nota 90).

8. Los máximos accionistas son D. Luis de la Riva, también director, y D. Francisco Piñeiro. A ellos se unen como socios D. José María Múñiz, D. Lorenzo Abad Martínez - comerciante de Madrid-, D. Andrés Fariña Martínez de Santiago de Compostela y D. Benito Abalo de Carril (Quiroga Figueroa 2003, 32).

9. De acuerdo con la última información que se ha podido recopilar en torno a la figura Edwin Forrester Heath - gran parte de ella gracias a la valiosa colaboración de uno de sus últimos descendientes en Galicia- sabemos que efectivamente nació en Burslem (Stafforshire) en 1817 siendo bautizado en julio de ese mismo año en la iglesia de St. John's, situada junto a la fábrica de cerámica de la familia Wedgwood.

Sus padres, se casaron en 1806, fueron John Forrester (1787-1835) y Catherine Heath (17821824), naturales de Bucknall y Caverswall en Staffordshire respectivamente.

Antes de su llegada a España, Edwin aparece censado en 1841 en el distrito alfarero de Wolstanton figurando como miembros de la familia, además de sus progenitores, su hermano Henry (vinculado a la fundición) y sus hermanas Catherine y Mary. Ya en Sargadelos estuvo relacionado con dos mujeres; la primera fue Antonia Pita Fernández con la que tuvo dos hijos, Guillermo (falleció muy joven) y Ana María Josefa (1847-1935). La segunda, María Antonia Abad Pérez (1831-1891) de cuya relación nacieron en el lugar de Viladesuso (Cervo): Victorina (1865-1936), José (1867-?) y Roberto (1868-?), estos últimos emigrados a Argentina entre 1888-1892.

$\mathrm{Su}$ regreso a Inglaterra, en la memoria familiar se dice que por motivos de salud y el deseo de morir en su lugar de origen, se produciría en una fecha posterior a 1868 volviendo a aparecer su nombre en el censo de Wolstanton en 1871 donde figura como gerente de alfarería. Allí fallece el 8 de agosto de ese mismo año siendo beneficiarios de su testamento su hermano Henry (tendero) y su cuñado Spencer Tomkinson (tendero y ceramista) casado con su hermana Mary desde 1858. Su funeral se celebró el 11 de agosto en la iglesia de St. Paul en Burslem. 
negro, castaño, rosa, violeta, azul, verde y el innovador azul cobalto a partir de 1854- las nuevas decoraciones: los llamados paisajes imaginarios o vistas fantásticas y las chinerías (ambos temas importados de Inglaterra -Weedgwood y Daventport-); las vistas reales (ciudades españolas y la isla de Cuba); piezas personalizadas con iniciales, anagramas o escudos; las que imitaban la textura de la piedra y el mármol (serie jaspeada y veteada); la serie infantil (con escenas de niños jugando) o la campesina (una mujer en un prado ordeñando una vaca). Un amplio repertorio decorativo al que se suma la que se conoce como serie de el Quijote en la que, como su nombre indica, se empleaban como elemento de decoración principal viñetas inspiradas en la novela cervantina, obra literaria en absoluta consonancia con los ideales románticos de la época.

\section{LA SERIE DECORATIVA DEL QUIJOTE}

Se desconoce el momento preciso y los motivos que llevaron a los entonces responsables de la factoría lucense a incluir en su producción esta variante (Rial López 2005, 164-177). A pesar de la popularidad de la que gozaba la novela, no existían en España otros centros de producción cerámica que sirviesen de referencia por haberla tomado como fuente de inspiración para sus productos. Los escasos ejemplos se remontaban a la segunda mitad del siglo XVIII; un pequeño número de piezas que se reducían a un plato de Talavera de la Reina; tres jarrones de la Real Fábrica de Porcelana del Buen Retiro decorados con escenas basadas en los dibujos del francés Charles Antoine Coypel y, por último, cuatro placas decorativas, una salvilla y una fuente redonda producidas en la Real Fábrica de Alcora ${ }^{10}$.

Una realidad que nada tenía que ver con la inglesa donde ya en el primer cuarto del siglo XIX había al menos dos factorías en las que se comercializaban piezas para el servicio de mesa cuyo motivo decorativo principal eran distintas escenas del Quijote (Gavin 2003, 127-143; Hyland 2005; Price 1948). Una de ellas fue Brameld \& Co., compañía responsable de la fábrica de porcelana fina de Rockingham, en Swinton (Yorkshire) desde el año 1806 hasta 1842 . De allí salieron en torno a 1830 vajillas completas con viñetas estampadas en un solo color (negro, azul o verde) inspiradas en los dibujos de Robert Cruikshank (1789-1856) y Thomas Stothard (1755-1834) utilizados originalmente para ilustrar sendas ediciones inglesas de la novela de Cervantes $^{11}$. A esta iniciativa se suma la de los hermanos Ralph y James Clews, en

10. Para más información sobre las piezas (Mañueco Santurtún 2005; José i Pitarch 2005; Feit 2017, 262-265).

11. Los dibujos de Thomas Stothard se utilizaron inicialmente para una edición londinense del año 1782, The History of the Renowned Don Quixote de la Mancha, impresa por Harrison \& Co. Muchos de ellos se volverían a imprimir en ediciones posteriores: Harrison (1792), John Sharpe (1809) y W. Miller (1810). Los dibujos de Robert Cruikshank, también grabados por diferentes artistas, 
Cobridge, cerca de Burslem, en la región de Stafforshire, donde desarrollaron su actividad entre 1818 y 1834 . A ellos se debe la serie en azul oscuro (dark blue) en la que se combina una orla decorativa en forma de estrella festoneada con pájaros y flores intercaladas, y un motivo principal estampado en el que se reproducen los dibujos para el Quijote de dos artistas: Robert Smirke (1752-1845) -ilustraron la edición de lujo de T. Cadell y W. Davis impresa en Londres en 1818-y Richard Westall (c. 1765-1836) para la correspondiente de Hurst, Robinson and Co. del año $1820^{12}$. Un total de quince escenas (Atlee Barber 1899, 49-50) entre las que se encuentran junto a otras el momento en que don Quijote es armado caballero, el encantamiento de Dulcinea o el manteamiento de Sancho, temas comunes a los utilizados para sus lozas en Sargadelos, donde lo más probable es que la llegada del nuevo director en torno a 1845 -procedente de la misma región de Staffordshire- hubiese sido determinante para que se iniciase la nueva serie decorativa. Es muy posible, dada la inexistencia ya apuntada de precedentes en España, que Forrester hubiese conocido los ejemplos ingleses y hubiese propiciado la introducción del mismo repertorio decorativo en la fábrica de la que ahora era el máximo responsable técnico. Esta suposición se apoya además en otra circunstancia que ahora ya podemos documentar, el hecho de que el modelo de inspiración para toda la serie proceda de Inglaterra, tal y como en su día ya apuntó el propio Felipe Bello Piñeiro $(1979,62)$, figura destacada en el estudio y divulgación a principios del siglo XX de la cerámica de Sargadelos.

Sin referencias en los catálogos de productos de la época, es factible pensar que esta variante decorativa se hubiese realizado en la fábrica luguesa de manera limitada y con destino a un público muy concreto que conociese y fuese capaz de apreciar lo que se le ofrecía. De hecho, en la actualidad y a expensas de futuros descubrimientos, no son muchos los ejemplares de los que se tenga constancia ${ }^{13}$. Se trata -salvo una palangana para el aseo y tres pequeños pedestales que podrían haber sido utilizados como pisapapeles- de piezas destinadas al servicio de mesa con tipologías comunes a las que conforman la única vajilla que se conoce de esta serie y que ha sido localizada recientemente. Un conjunto excepcional, propiedad de un coleccionista particular, compuesto por más de 50 piezas entre las que se encuentran, además de los platos (llanos, soperos y de sobremesa), distintos tipos de fuentes, le-

aparecieron por primera vez en una edición londinense de Knight and Lacey del año 1824: The life and exploits of Don Quixote de la Mancha reimprimiéndose posteriormente en las de Jones \& Co. de 1828 y 1837. Para la consulta de las distintas ediciones véase: <cervantes.dh.tamu.edu/V2/CPI/index. html $>$ y $<$ cervantesvirtual.com/portales/quijote_banco_imagenes_qbi/>. Fecha de acceso: 15 de septiembre de 2020.

12. Véanse para la consulta de ambas ediciones: $<$ cervantes.dh.tamu.edu/V2/CPI/index.html $>$ y $<$ cervantesvirtual.com/portales/quijote_banco_imagenes_qbi/>.

13. Se han contrastado más de sesenta colecciones, tanto públicas como privadas. De las primeras destaca la del Museo de Pontevedra donde se conservan diez piezas, dos de ellas de especial singularidad por estar estampadas e iluminadas a mano. Le siguen el Museo de Bellas Artes de La Coruña y el Museo de Lugo, cada uno de ellos con tres. 
gumbreras, soperas, una salsera, un frutero en forma de concha y cuatro jícaras para el chocolate.

Las marcas de fábrica utilizadas para certificar la autenticidad de su elaboración en Sargadelos, se corresponden con las propias de la tercera etapa de producción de la factoría. Se trata del sello en el que aparece la corona real circunscrita por el texto REAL FABRICA. SARGADELOS, con una medida aproximada de $2,5 \mathrm{~cm}$ de diámetro. Aparece, en aquellas que lo presentan, en la base -bajo cubierta- grabado en seco o estampado (generalmente en el mismo color que la decoración de la pieza) de forma individual o incluso combinando ambas técnicas de aplicación.

En lo relativo a la decoración, los colores empleados para el estampado de los distintos modelos fueron el negro (algunos se iluminaron a mano en varios tonos), el verde, el azul, el rojo y también el violeta. Acompañando a la viñeta principal y como en las demás series decorativas de Sargadelos se añadieron las correspondientes orlas y ribetes con las que se unificaban las distintas piezas de un mismo conjunto. Los modelos empleados fueron los habituales para la tercera época: la orla "isabelina"; la de tipo corrido con decoración floral en la que se alternaban pequeños grupos de flores diminutas con hojas dentadas sobre un fondo de tul y un remate interno de crestería; la de empedrados y la orla corrida chinesca. Los ribetes - de perlas y rosáceas, geométricos o en forma de cadeneta floral- se reservaron para las piezas de pequeño tamaño.

Todos ellos complementarían los motivos decorativos principales, un total de nueve viñetas en las que se representan diferentes escenas del Quijote que se corresponden con distintos episodios de las dos partes de la novela. De la primera, publicada por Miguel de Cervantes en 1605: Don Quijote en la venta (cap. 2), Don Quijote es armado caballero (cap. 3), Manteamiento de Sancho (cap. 17), Conversación entre don Quijote y Sancho sobre el buen caballero andante (cap. 21) y la Aventura de los disciplinantes (cap. 52). De la segunda parte, publicada en 1615: El encantamiento de Dulcinea (cap. 10), La aventura de los leones (cap. 17), Sancho, juez de Barataria (cap. 45) y El final del gobierno de Sancho (cap. 53). Una identificación que hasta el momento era el único dato de referencia que existía para una serie de la que se desconocía la fuente de inspiración. Una circunstancia que ha cambiado al poder visualizar las distintas ediciones ilustradas del Quijote que se recogen en las principales bases de datos dedicadas a su recopilación ${ }^{14}$. De este modo, las suposiciones de estudios anteriores han dado paso a datos contrastados que permiten afirmar con absoluta certeza que el modelo iconográfico para la decoración de las piezas cerámicas de la serie que nos ocupa, fueron las láminas con grabados utilizadas originalmente para ilustrar una edición londinense del Quijote, la de Charles Daly para el año 1842. Una edición «muy bien impresa con tipos pequeños pero claros» (Suñe Benages y Suñe Fonbuena 1917,264$)$ de la que la Biblioteca Nacional de España conserva un ejemplar en $8 .^{\circ}$ mayor, con 507 páginas a dos columnas. Contiene -además del

14. <http://cervantes.dh.tamu.edu $>$; <cervantesvirtual.com/portales/quijote_banco_imagenes_qbi/>. 
prefacio del editor, la vida de Cervantes, prólogo, texto e índice- dos frontispicios, una página con el título ilustrado y 16 ilustraciones para capítulos (intercaladas entre páginas del texto) diseñadas por el reconocido pintor e ilustrador inglés John Gilbert (1817-1897) ${ }^{15}$ y grabadas en madera por Folkard $^{16}$, J. Walmsley ${ }^{17}$, C. Armstrong ${ }^{18}$, Slaver y otros artistas anónimos.

Las escenas escogidas para acompañar los textos de la que era considerada por los románticos como «una ejemplar exaltación de los valores caballerescos» (Ardila 2005, 254; Torres Santo Domingo 2005) fueron realizadas tomando como referencia ocho capítulos de cada una de las partes. De acuerdo con el particular modelo editorial inglés nos encontramos, al igual que en otras ediciones del mismo país (Givanel i Mas 1946; Hadegorn 2009; Lena-

15. Dotado de una calidad innata para el dibujo, iniciará su formación en el estudio del reconocido pintor de frutas George Lance, discípulo a su vez de Hayden, con quien permanecerá durante algún tiempo compaginándolo con su constante e ininterrumpida formación autodidacta.

$\mathrm{Su}$ debut como artista se produjo en 1836 con la exhibición de algunos de sus dibujos en la importante Sociedad de artistas británicos de Suffolk Street. Un año después comenzaría su colaboración con la también prestigiosa British Institution donde mostraría algunos óleos de excelente calidad y gran formato entre los que ya se encontraban los primeros ejemplos dedicados a la figura del Quijote: «Don Quijote y Sancho Panza» (1840) -actualmente en el Victoria and Albert Museum de Londres- y «El Duque promete a Sancho el gobierno de una isla» (1842).

Aunque valorado por sus trabajos con el pincel, en los que el Quijote seguiría teniendo un protagonismo importante, su principal ocupación fue la ejecución de dibujos en blanco en negro para ilustraciones de libros y periodismo pictórico (Illustred London News y Diary of London), actividad por la que acabaría siendo más reconocido. Sus ilustraciones más famosas, además de las de muchos libros de poetas ingleses, cuentos infantiles y novelas juveniles, fueron las que diseñó para la edición de Shakespeare de Howard Staunton publicada a partir de 1856. Un autor clásico a cuya devoción se sumaba la que sentía por Walter Scott y Cervantes, motivo que quizás en el último de los casos fuese la causa principal que le llevase a realizar los dibujos en madera para la edición del Quijote de Charles Daly de 1842 .

En 1852 pasó a formar parte de la Royal Water Color Society de la que sería designado Presidente en 1871 y donde llegaría a exhibir hasta 270 acuarelas.

Nombrado Caballero de la Legión de Honor tras su gran éxito en la Exposición de París de 1878, pasaría a la historia como un gran ilustrador, destacando por encima de todo su calidad como dibujante. Llegaría a dominar una gran variedad de métodos y técnicas artísticas, siendo capaz de dibujar sobre madera, piedra, papel o metal con idéntica calidad. A ello se sumaba su habilidad con la pintura al óleo, con las técnicas al agua y frescos, con la representación de figuras y rostros en miniatura además de los aguafuertes. Su producción fue inagotable atribuyéndosele unas 400 pinturas y más de 40.000 dibujos.

Murió en 1897 y tras su fallecimiento fueron numerosas las crónicas dedicadas a su figura donde de manera general se exaltaba su gran calidad artística.

Para más datos sobre su biografía y su trayectoria artística véase: $<$ www.britannica.com $>$; $<$ http:// artistsathome.emorydomains.org/exhibits/show/victorian-artists-at-home/item/47>. Fecha de acceso: 21 de septiembre de 2020.

Para conocer su obra y las distintas colecciones y museos donde se puede encontrar: $<$ https:// artuk.org/discover/artists/gilbert-john-18171897>. Fecha de acceso: 21 de septiembre de 2020.

16. Es probable que se corresponda con William Armstrong Folkard, grabador inglés en madera activo entre 1830 y 1850 . Accesible en: <https://www.britishmuseum.org/collection/term/BIOG27460>. Fecha de acceso: 21 de septiembre de 2020.

17. Grabador en madera inglés activo entre 1838-1878.

18. Por cronología no puede tratarse de Cosmo Armstrong, fallecido en 1836, seis años antes de la fecha de edición del Quijote de Charles Daly. Es más probable que se corresponda con el grabador C. Armstrong también inglés y activo en la segunda mitad del siglo XIX que al parecer cursó estudios en la South Kensington College of Engraving donde expuso uno de sus trabajos (Benezit 2012, 47). 
gham 2003), con un lenguaje iconográfico uniforme conseguido por haber sido un único artista el encargado de la ejecución de todos los dibujos. En él recayó la responsabilidad de que las ilustraciones incluidas en la presente edición constituyesen, como en el resto de las inglesas, una pieza fundamental, no un mero adorno, indispensable para la comprensión de todo aquello que no se puede expresar con palabras (Close 2005; Lucía Megías 2005, 121 151; Lucía Megías 2006; Luttikhuizen 2005). Para ello Gilbert realizó 16 dibujos que intercalados con el texto ayudaban a visualizar algunos de los episodios de los distintos capítulos. Fueron los siguientes: Don Quijote en la venta (I, cap. 2), Don Quijote es armado caballero (I, cap. 3), Aventura del vizcaíno (I, cap. 9), Manteamiento de Sancho (I, cap. 17), Aventura de la princesa Micomicona (I, cap. 29), Aventura de los cueros de vino (I, cap. 35), Aventura de los disciplinantes (I, cap. 52), Llegada a la aldea (I, cap. 52), El encantamiento de Dulcinea (II, cap. 10), Visiones dentro de la Cueva de Montesinos (II, cap. 23), Sancho y la Duquesa (II, cap. 33), Aventura de la Dueña Dolorida (II, cap. 39), Sancho, juez de Barataria (II, cap. 45), El final del gobierno de Sancho (II, cap. 53), Don Quijote en Barcelona (II, cap. 62) y Muerte de Alonso Quijano (II, cap. 74). Reproducidos con la técnica de la xilografía, volvieron a ser utilizados para ilustrar nuevas ediciones como la londinense de Henry Bonn (Cervantes 1842) para el mismo año 1842 donde además se incluían los grabados realizados por Tony Johannot que ya habían aparecido en una edición de la novela de 1836-1837 (Cervantes 1836-1837). Una publicación esta última con la que se inauguraba en su momento un nuevo periodo en la recepción del Quijote en el que se potenciaba una lectura erudita y moralizante, alejada de la imaginación, la fantasía y lo irracional (González Moreno 2009, 343-368; González Moreno y Urbina 2011, $315-$ 326). En base a estas premisas realizaría sus diseños Johannot, un total de 768 xilografías que como algo novedoso aparecerían en combinación con el cuerpo del texto. Una apuesta que contribuyó al enorme éxito de la edición original que el propio Gilbert tomaría como modelo de inspiración para algunos de sus dibujos. Es el caso de la llegada a la venta de las mozas, el manteo de Sancho, la aventura con los disciplinantes o el encantamiento de Dulcinea; viñetas que tienen en común el hecho de encontrarse entre el grupo de las seleccionadas por Sargadelos para la decoración de sus lozas.

A la certeza de la fuente de inspiración de origen -a la que es probable que accediesen a través de un ejemplar impreso de la novela quizás traído desde Inglaterra por el propio director artístico de la fábrica o algún otro técnico de idéntica procedencia- se suman una serie de incógnitas tales como el motivo que les llevó a escoger unas imágenes en detrimento de las otras (quizás la mejor adaptación a la morfología de las piezas) o si el repertorio se correspondería en origen (pueden haberse perdido objetos cerámicos) con la totalidad de ilustraciones diseñadas por el dibujante inglés para la edición de 1842. Un aspecto este último que no considero probable si tomamos como referencia las lozas conservadas pues aun teniendo tipologías muy diferentes, las mismas estampas se aplican repetidamente y de manera indistinta a unas 
y otras, variando únicamente el tamaño y el color. La técnica decorativa empleada para tal fin fue la del estampado mecánico, común a las demás fábricas españolas de la época, donde se habría introducido como en Sargadelos gracias a la llegada de técnicos extranjeros. El grabador responsable de los diseños en esa tercera etapa, José María Gómez (establecido allí desde 1838), se encargaría fundamentalmente de copiar, adaptar y reinterpretar los modelos ya grabados en planchas de acero y cobre importadas de Inglaterra ${ }^{19}$. Un trabajo de «adaptación» al que se sumarían las creaciones originales, aquellas en las que se partía de una plancha en blanco sobre la que se dibujaban los distintos motivos diseñados previamente. Un modo de hacer que con toda probabilidad sería el utilizado para la creación de la serie decorativa del Quijote donde los dibujos sobre el metal se habrían hecho inspirándose directamente en las ilustraciones contenidas en la edición inglesa de la que parte.

La comparación individualizada entre los originales de Gilbert y cada una de las imágenes transferidas a las piezas de cerámica nos permite ver las diferencias entre estas y los dibujos que ilustraban las ediciones en papel, lo que reafirma la teoría anterior descartando la utilización de planchas ya grabadas traídas desde Inglaterra. Así y a pesar de mantener la misma composición, personajes y la mayor parte de elementos accesorios, nos encontramos con algunas modificaciones en las que destaca un dibujo más simplificado, de menor calidad, la eliminación de algunos detalles y la incorporación de otros, especialmente para completar la decoración de las piezas más grandes. En las más pequeñas, como pueden ser las jícaras, las diferencias con el original son más evidentes, viéndose una mayor simplicidad e incluso pequeñas alteraciones respecto a las lozas de más tamaño e idéntica viñeta. Todo ello corrobora la intervención creativa de un grabador, José Gómez u otro, que formaría parte de la plantilla de Sargadelos y se habría encargado de interpretar con cierta libertad y de acuerdo con sus dotes artísticas los modelos de referencia con los que contó.

\section{CATÁLOGO DE PIEZAS Y REPERTORIO ICONOGRÁFICO}

Hasta la fecha se contabilizan, entre colecciones públicas y privadas y con la posibilidad de que puedan aparecer más ejemplares todavía no localizados, un total de 89 piezas de las que 34 son ejemplares sueltos que con toda probabilidad habrían formado parte de un conjunto mayor, posiblemente de alguna de las vajillas que la fábrica luguesa ofrecía a sus clientes a través de los correspondientes catálogos de productos ${ }^{20}$.

19. Bello Piñeiro, Felipe. 1919. Sargadelos. Su pasado y su porvenir (texto manuscrito). Archivo Documental del Museo de Pontevedra, Archivo general 47-10.

20. En los catálogos de productos de la época, sirve de ejemplo uno correspondiente a junio de 1847, se ofrecían, en función del número de comensales, tres tipos de «Bajilla de loza fina estampada». Así nos encontramos con una para 24 personas, otra para 12 y finalmente para 8 , reduciéndose progresivamente el número y variedad de piezas. Cada una de ellas, como se recoge en el mismo 
El análisis de todas ellas nos permite determinar que al menos se realizaron cuatro variantes decorativas. Los modelos más numerosos son los que tienen como elemento unificador la orla isabelina y los colores más utilizados el castaño y el negro seguidos del verde, el azul y el rojo ${ }^{21}$. A los anteriores se suman cuatro platos de color violeta con orla de tipo corrido con decoración floral y otro en verde con orla de empedrados. Completan el repertorio tres piezas singulares que se diferencian de las anteriores por estar iluminadas en rojo, azul y verde: un plato estampado en negro, de colección particular, con orla de tipo corrido floral y la viñeta central Sancho. Juez de Barataria; una jarra de pico - personalizada con las iniciales del propietario y rematada con ribete de perlas y rosáceas- y otro plato, también en negro, con orla corrida chinesca, ambas de la colección del Museo de Pontevedra.

Tomando como modelo de referencia algunas de las piezas conservadas -en su mayoría las que forman parte de la ya citada colección del Museo de Pontevedra- es posible mostrar toda la serie decorativa junto a cada uno de los grabados originales escogidos para aplicar a las distintas lozas. Son los siguientes:

\section{Don Quijote en la venta. Don Quijote conversa con las dos mozas a la entrada de la venta (I, cap. 2)}

La viñeta que adorna una de las caras de la jarra de Sargadelos (Fig. 1) reproduce de manera casi exacta la composición de la estampa grabada por J. Walmsley por dibujo de John Gilbert para la edición londinense de 1842 de Charles Daly (Fig. 2). Esta aparece como ilustración en el capítulo 2 del volumen I, entre las páginas 32 y 33, que «trata de la primera salida que de su tierra hizo el ingenioso Don Quijote». La escena recoge el momento en que don Quijote llega hasta una venta para pasar la noche. Convencido de que en realidad es un castillo, interpreta que dos jóvenes de dudosa reputación que están en la puerta de la misma son en realidad hermosas doncellas que habitan en la fortaleza y decide entablar una conversación:

En esto, sucedió acaso que un porquero que andaba recogiendo de unos rastrojos una manada de puercos -que, sin perdón, así se llaman- tocó un cuerno, a cuya señal ellos se recogen, y al instante se le representó a don Quijote lo que deseaba, que era que algún enano hacía señal de su venida; y así, con estraño contento, llegó a la venta y a las damas, las cuales, como

catálogo, debía complementarse con un surtido adicional -valorado en 120 reales de vellón- en el que se incluían: «1 juego de café con 31 piezas; 1 dicho de lavamanos, jarro y orinal; 1 docena jícaras; 1 idem tazas para caldo; 1 idem hueveros; 6 platos chicos; 1 jarro para agua; 1 escupidera».

21. A esta relación habría que añadir dos platos que en su día se encontraban en el Instituto de Estudios Gallegos «Padre Sarmiento» de Santiago de Compostela. Aparecen reproducidos en blanco y negro en un trabajo de José Filgueira Valverde sobre Sargadelos publicado en 1951 por Bibliófilos Gallegos, razón por la cual es imposible determinar el color de los mismos. 


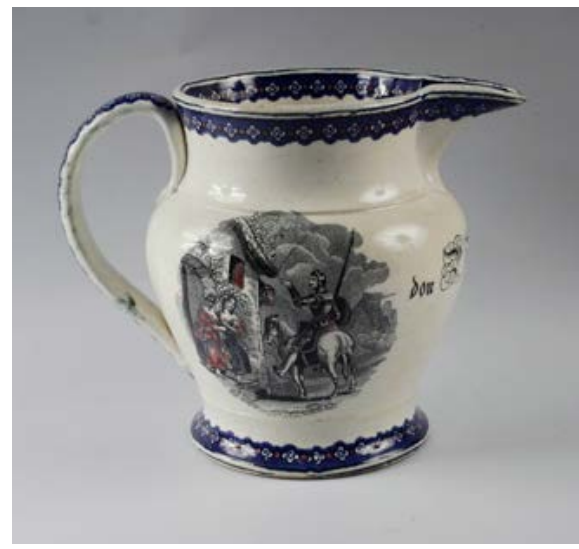

Figura 1. Jarra de pico iluminada con ribete de perlas y rosáceas. Museo de Pontevedra (N. ${ }^{\circ}$ Reg. 3151).

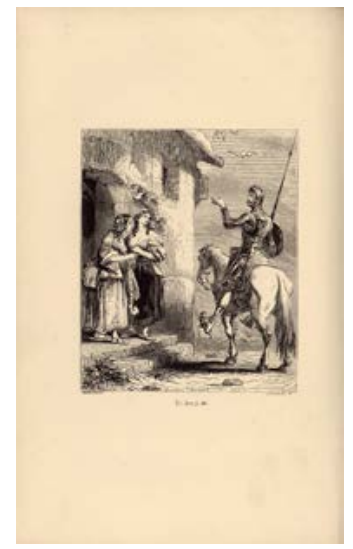

FIGURA 2. J. Walmsley por dibujo de John Gilbert. Don Quijote en la venta. Don Quijote conversa con las dos mozas a la entrada de la venta (I, cap. 2). Estampa n. ${ }^{\circ} 1$ en Don Quixote de la Mancha, Londres, Charles Daly, 1842. Imágenes del archivo digital «Iconografía textual del Quijote»<http://cervantes. dh.tamu.edu $>$, Proyecto Cervantes, Texas A\&M University.

vieron venir un hombre de aquella suerte, armado y con lanza y adarga, llenas de miedo, se iban a entrar en la venta; pero don Quijote, coligiendo por su huida su miedo, alzándose la visera de papelón y descubriendo su seco y polvoroso rostro, con gentil talante y voz reposada, les dijo:

-No fuyan las vuestras mercedes ni teman desaguisado alguno; ca a la orden de caballería que profeso non toca ni atañe facerle a ninguno, cuanto más a tan altas doncellas como vuestras presencias demuestran.

Mirábanle las mozas, y andaban con los ojos buscándole el rostro, que la mala visera le encubría; mas, como se oyeron llamar doncellas, cosa tan fuera de su profesión, no pudieron tener la risa, y fue de manera que don Quijote vino a correrse y a decirles:

-Bien parece la mesura en las fermosas, y es mucha sandez además la risa que de leve causa procede; pero no vos lo digo porque os acui-tedes ni mostredes mal talante; que el mío non es de ál que de serviros ${ }^{22}$.

De acuerdo con el relato, se representa a don Quijote vestido con armadura a lomos de su caballo conversando en actitud galante con dos mujeres que se encuentran en la entrada de una pequeña construcción de piedra. Una composición sencilla en la que toda la atención recae en los protagonistas del episodio. Es en la viñeta transferida a la jarra donde se ha buscado una mayor 
profusión decorativa añadiendo vegetación en varios puntos y destacando el fondo con masas de nubes y montañas.

Este motivo fue aplicado también a platos y otras piezas de tamaño más reducido, como las jícaras (Museo de Bellas Artes de La Coruña, N. ${ }^{\circ}$ Inv.: 4164) y alguno de los pedestales (Museo de Pontevedra, N. ${ }^{\circ}$ Reg. 3038) donde se mantiene el esquema compositivo pero se simplifican los fondos y se eliminan o reducen los elementos vegetales que completan la escena.

\section{Don Quijote es armado caballero. El ventero ordena caballero a don Quijote (I, cap. 3)}

La viñeta decorativa del plato (Fig. 3) reproduce sin apenas variaciones la composición del grabado realizado por C. Armstrong \& Son por dibujo de John Gilbert para ilustrar, entre las páginas 36 y 37, el capítulo 3 del volumen I de la misma edición de Charles Daly de 1842 (Fig. 4). Un episodio de gran trascendencia en el que se cuenta «la graciosa manera que tuvo don Quijote en armarse caballero»:

Advertido y medroso desto el castellano, trujo luego un libro donde asentaba la paja y cebada que daba a los arrieros, y con un cabo de vela que le traía un muchacho, y con las dos ya dichas doncellas, se vino adonde don

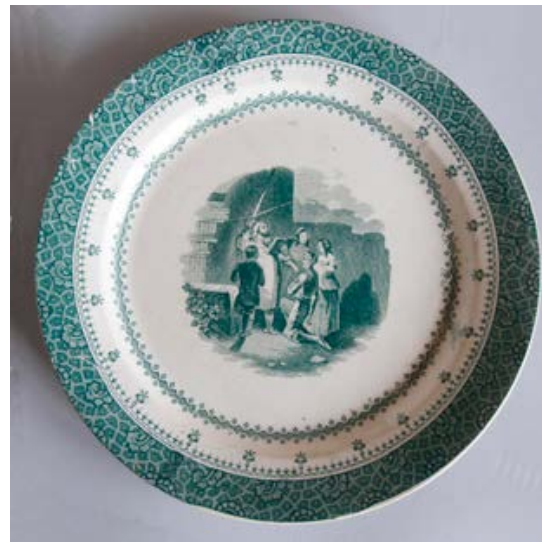

FIgURA 3. Plato llano en verde con orla de empedrados. Museo de Pontevedra (N. ${ }^{\circ}$ Reg. 14.706).

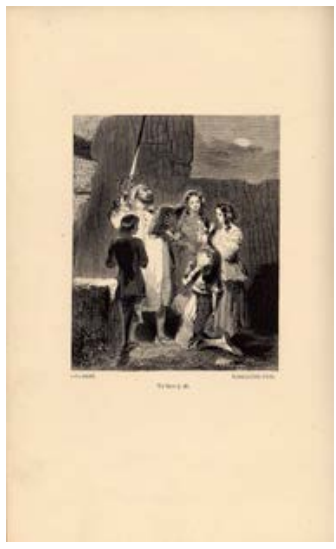

FIgURA 4. C. Armstrong \& Son por dibujo de John Gilbert. Don Quijote es armado caballero. El ventero ordena caballero a Don Quijote (I, cap. 3). Estampa n. ${ }^{\circ} 2$ en Don Quixote de la Mancha, Londres, Charles Daly, 1842. Imágenes del archivo digital "Iconografía textual del Quijote" <http://cervantes. dh.tamu.edu>, Proyecto Cervantes, Texas A\&M University. 
Quijote estaba, al cual mandó hincar de rodillas; y, leyendo en su manual, como que decía alguna devota oración, en mitad de la leyenda alzó la mano y diole sobre el cuello un buen golpe, y tras él, con su mesma espada, un gentil espaldarazo, siempre murmurando entre dientes, como que rezaba. Hecho esto, mandó a una de aquellas damas que le ciñese la espada, la cual lo hizo con mucha desenvoltura y discreción, porque no fue menester poca para no reventar de risa a cada punto de las ceremonias; pero las proezas que ya habían visto del novel caballero les tenía la risa a raya. Al ceñirle la espada, dijo la buena señora:

-Dios haga a vuestra merced muy venturoso caballero y le dé ventura en lides.

De acuerdo con ello aparece don Quijote en primer plano de rodillas y vestido con su armadura, acompañado por las dos mozas de la venta, un muchacho y el propio ventero que con espada en mano y en ropa de dormir se dispone a armarlo caballero. Todo ello en un espacio exterior, con la luna ligeramente visible al fondo y rodeados por restos de arquitecturas, de estilo clásico en la estampa transferida a la pieza de loza, donde además se han añadido una mayor cantidad de elementos vegetales (maleza en la parte anterior del muro).

Esta escena fue aplicada también a la jarra iluminada del Museo de Pontevedra (Fig. 1) en combinación con la ya comentada Don Quijote en la venta dispuesta en la cara opuesta. Puede verse además en un plato llano de color violeta acompañado por una orla corrida con decoración floral (Museo de Pontevedra, N. ${ }^{\circ}$ Reg. 313).

\section{Manteamiento de Sancho: Sancho por los aires en el corral de la venta; don Quijote se encarama a un muro de la venta (I, cap. 17)}

En este plato (Fig. 5) se ha transferido la estampa número 4 de la misma edición de Charles Daly para 1842 (Fig. 6). Fue realizado por J. Walmsley por dibujo de John Gilbert e ilustraba el capítulo 17 del tomo I -entre las páginas 84 y 85 - donde se «prosiguen los innumerables trabajos que el bravo don Quijote y su buen escudero Sancho Panza pasaron en la venta que, por su mal, pensó que era castillo». El momento concreto escogido para reproducir, es aquel en el que Sancho es manteado por varios hombres en el corral de la venta donde había pasado la noche, junto a don Quijote, y de donde pretendían partir sin pagar el alojamiento:

Y allí, puesto Sancho en mitad de la manta, comenzaron a levantarle en alto y a holgarse con él como con perro por carnestolendas.

Las voces que el mísero manteado daba fueron tantas, que llegaron a los oídos de su amo; el cual, determinándose a escuchar atentamente, creyó que alguna nueva aventura le venía, hasta que claramente conoció que el 

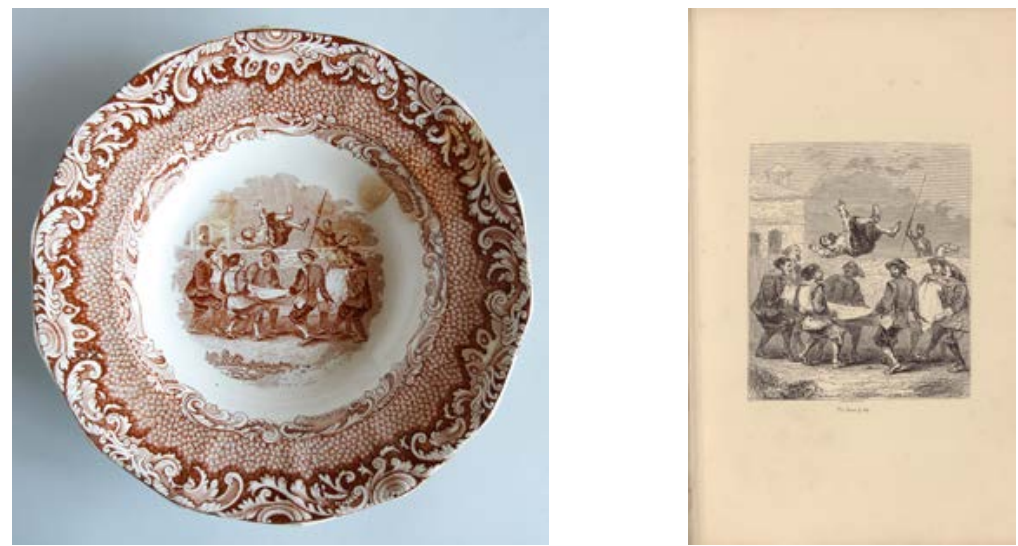

Figura 5. Plato sopero en castaño con Figura 6. J. Walmsley por dibujo de John orla isabelina. Museo de Pontevedra (N. ${ }^{\circ}$ Gilbert. Manteamiento de Sancho: Sancho Reg. 3.152). por los aires en el corral de la venta; don Quijote se encarama a un muro de la venta (I, cap. 17)). Estampa n. ${ }^{\circ} 4$ en Don Quixote de la Mancha, Londres, Charles Daly, 1842. Imágenes del archivo digital "Iconografía textual del Quijote" $<$ http://cervantes.dh.tamu.edu $>$, Proyecto

Cervantes, Texas A\&M University.

que gritaba era su escudero; y, volviendo las riendas, con un penado galope llegó a la venta, y, hallándola cerrada, la rodeó por ver si hallaba por donde entrar; pero no hubo llegado a las paredes del corral, que no eran muy altas, cuando vio el mal juego que se le hacía a su escudero. Viole bajar y subir por el aire, con tanta gracia y presteza que, si la cólera le dejara, tengo para mí que se riera. Probó a subir desde el caballo a las bardas, pero estaba tan molido y quebrantado que aun apearse no pudo; y así, desde encima del caballo, comenzó a decir tantos denuestos y baldones a los que a Sancho manteaban, que no es posible acertar a escribillos; mas no por esto cesaban ellos de su risa y de su obra, ni el volador Sancho dejaba sus quejas, mezcladas ya con amenazas, ya con ruegos; mas todo aprovechaba poco, ni aprovechó, hasta que de puro cansados le dejaron.

Al igual que en los ejemplos anteriores se mantiene la composición con respecto al grabado original: en un patio exterior un grupo formado por siete hombres levanta en el aire con una manta a Sancho. Tras ellos, un muro de media altura en el que sobresale la figura de don Quijote en su caballo increpando con su lanza a los responsables de la humillación de su escudero.

Las diferencias con el dibujo de Gilbert se reducen básicamente al tratamiento de los rostros de cada una de las figuras que aunque mantienen la misma disposición y el mismo tipo de indumentaria, fueron ejecutados con una mayor simplicidad y en consecuencia falta de expresividad. 
La adaptación a la morfología de la pieza ha hecho necesario además que se corte parcialmente la arquitectura situada en el lateral izquierdo, donde se ha suprimido también la chimenea que se veía en la ilustración de origen.

Para las piezas de mayor tamaño (dos fuentes, una legumbrera, una sopera y una palangana, esta última de la colección del Museo Provincial de Lugo) se utilizó una viñeta que reinterpretaba con mayor libertad el diseño original: se modificó la construcción situada en el margen izquierdo, se añadió vegetación en varios puntos de la escena y el fondo se cerró con montañas (Fig. 7).

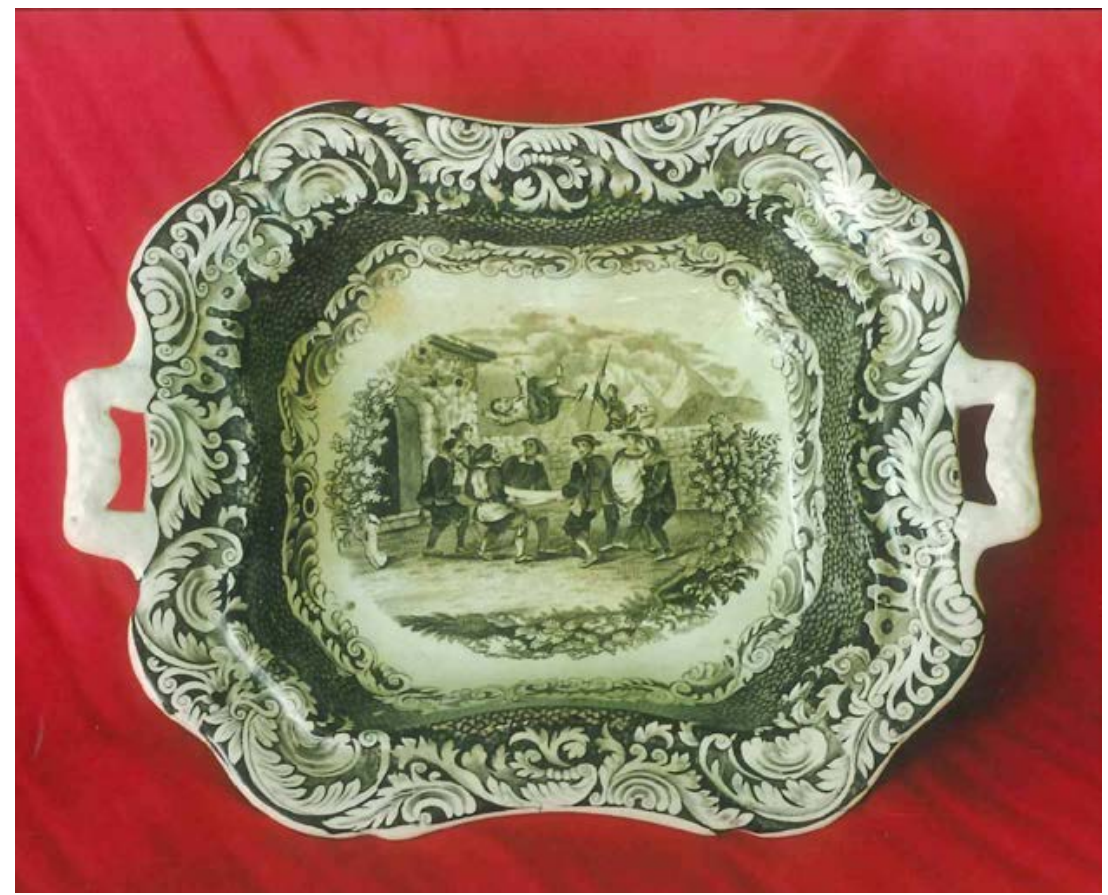

FiguRA 7. Legumbrera en negro con orla isabelina. Colección particular.

\section{Conversación entre don Quijote y Sancho sobre el buen caballero andante (I, cap. 21)}

En este ejemplo, estampado en azul, la imagen seleccionada para transferir a la pieza de loza (Fig. 8) se corresponde con un fragmento del grabado realizado por Folkard por dibujo de John Gilbert para el frontispicio de la misma edición de Charles Daly de 1842 (Fig. 9). Se trata del motivo central en el que aparecen don Quijote y Sancho en sus respectivas monturas de camino a algún punto, el primero gesticulando al mismo tiempo que habla y el segundo cabizbajo escuchando lo que el anterior le dice. Este momento forma parte del capítulo 21 del tomo I que trata «de la alta aventura y rica 


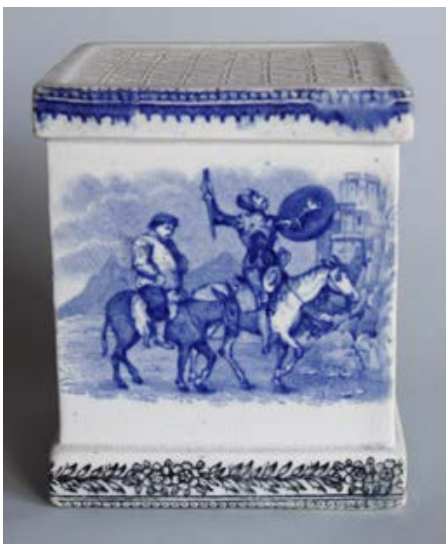

Figura 8. Pedestal con escena del Quijote estampada en azul. Museo de Pontevedra (N. ${ }^{\circ}$ Reg. 3.038).

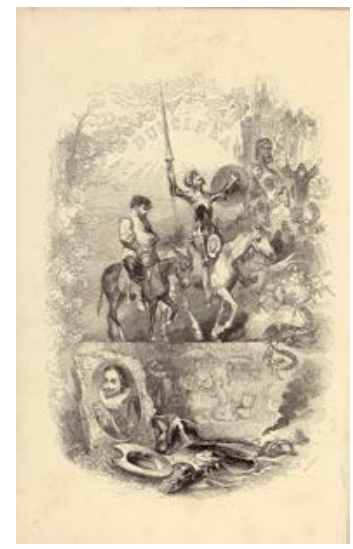

Figura 9. Folkard por dibujo de John Gilbert. Conversación entre don Quijote y Sancho sobre el buen caballero andante (I, cap. 21). Frontispicio en Don Quixote de la Mancha, Londres, Charles Daly, 1842. Imágenes del archivo digital "Iconografía textual del Quijote" $<$ http://cervantes.dh.tamu.edu $>$, Proyecto

Cervantes, Texas A\&M University.

ganancia del yelmo de Mambrino, con otras cosas sucedidas a nuestro invencible caballero»:

-No dices mal, Sancho -respondió don Quijote-; mas, antes que se llegue a ese término, es menester andar por el mundo, como en aprobación, buscando las aventuras, para que, acabando algunas, se cobre nombre y fama tal que, cuando se fuere a la corte de algún gran monarca, ya sea el caballero conocido por sus obras; y que, apenas le hayan visto entrar los muchachos por la puerta de la ciudad, cuando todos le sigan y rodeen, dando voces, diciendo: "Éste es el Caballero del Sol”, o de la Sierpe, o de otra insignia alguna, debajo de la cual hubiere acabado grandes hazañas. "Éste es - dirán- el que venció en singular batalla al gigantazo Brocabruno de la Gran Fuerza; el que desencantó al Gran Mameluco de Persia del largo encantamento en que había estado casi novecientos años.

La transferencia de esta escena a una pieza de pequeño tamaño ha obligado, a pesar de seguir manteniendo la composición, a agrupar los distintos elementos (las montañas y el castillo de fondo) así como a eliminar parte de otros (la lanza de don Quijote se ha acortado).

Esta viñeta se encuentra únicamente, siempre tomando como referencia los ejemplares conservados, en objetos de pequeño formato (jícaras, cucharón y pedestales) en los colores azul, negro y verde. 


\section{Aventura de los disciplinantes. Combate entre don Quijote y unos de los que llevaban a la Virgen (I, cap. 52)}

La viñeta en rojo que decora el pedestal (Fig. 10) se corresponde con la ilustración para el capítulo 52 del tomo I -correspondiente a la edición londinense de Charles Daly para el año 1842 - en el que se recoge «la pendencia que don Quijote tuvo con el cabrero, con la rara aventura de los disciplinantes, a quien dio felice fin a costa de su sudor» (Fig. 11). Realizado por un grabador anónimo a partir del dibujo original de John Gilbert, se dispuso entre las páginas 242 y 243 mostrando el momento en que don Quijote combate con su espada y sobre su caballo contra uno de los disciplinantes que llevaban a la Virgen en procesión y que él había confundido con una dama en apuros que era necesario liberar:

En estas razones, cayeron todos los que las oyeron que don Quijote debía de ser algún hombre loco, y tomáronse a reír muy de gana; cuya risa fue poner pólvora a la cólera de don Quijote, porque, sin decir más palabra, sacando la espada, arremetió a las andas. Uno de aquellos que las llevaban, dejando la carga a sus compañeros, salió al encuentro de don Quijote, enarbolando una horquilla o bastón con que sustentaba las andas en tanto que descansaba; y, recibiendo en ella una gran cuchillada que le tiró don Quijote, con que se la hizo dos partes, con el último tercio, que le quedó en la mano, dio tal golpe a don Quijote encima de un hombro, por el mis-

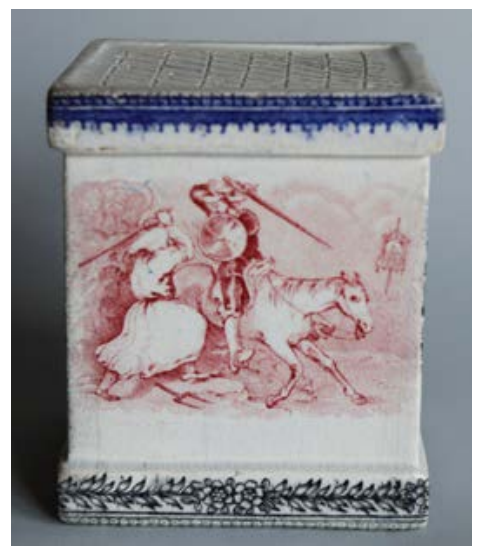

Figura 10. Pedestal con escena del Quijote estampada en rojo. Museo de Pontevedra (N. ${ }^{\circ}$ Reg. 3.038).

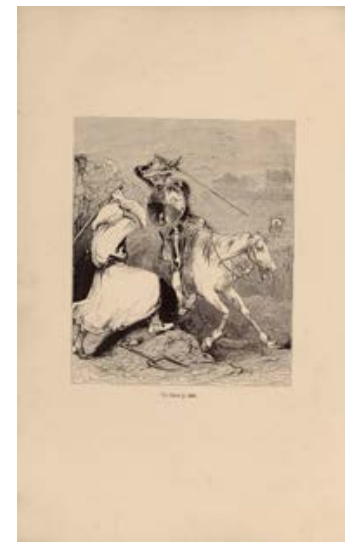

Figura 11. Anónimo por dibujo de John Gilbert. Aventura de los disciplinantes.

Combate entre don Quijote y unos de los que llevaban a la Virgen (I, cap. 52).

Estampa n. ${ }^{\circ} 7$ en Don Quixote de la

Mancha, Londres, Charles Daly, 1842.

Imágenes del archivo digital «Iconografía textual del Quijote»> $<$ ttp://cervantes.

dh.tamu.edu $>$, Proyecto Cervantes, Texas A\&M University. 
mo lado de la espada, que no pudo cubrir el adarga contra villana fuerza, que el pobre don Quijote vino al suelo muy mal parado.

La escena fue transferida a piezas de diferentes dimensiones y formatos (pedestal, jícara, platos) en los colores negro, rojo, azul y verde, manteniendo con total fidelidad la composición, personajes y elementos accesorios de la plancha que emplearon como fuente de inspiración.

\section{El encantamiento de Dulcinea. Don Quijote y Sancho se postran ante Dulcinea encantada (II, cap. 10)}

La escena representada (Fig. 12) sirvió para ilustrar el capítulo 10 del tomo II de la misma edición londinense de Charles Daly de 1842 (Fig. 13). El grabado, realizado en este caso por C. Armstrong a partir del dibujo original de John Gilbert, se dispuso entre las páginas 284 y 285 sirviendo como ilustración para el episodio «donde se cuenta la industria que Sancho tuvo para encantar a la señora Dulcinea, y de otros sucesos tan ridículos como verdaderos».

El momento escogido es aquel en que don Quijote y Sancho se postran ante la que se supone es Dulcinea encantada. Un engaño urdido por el propio

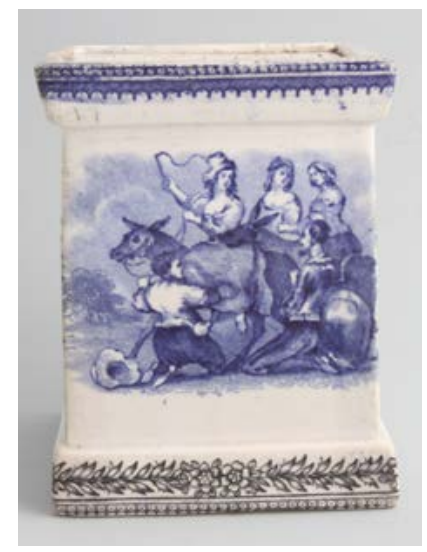

Figura 12. Pedestal con escena del Quijote estampada en azul. Museo de Pontevedra (N. ${ }^{\circ}$ Reg. 15.911).

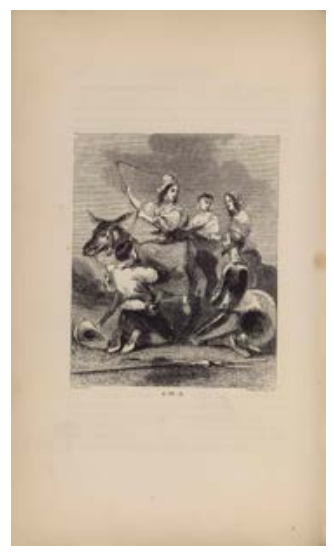

FigURA 13. C. Armstrong por dibujo de John Gilbert. El encantamiento de

Dulcinea. Don Quijote y Sancho se postran ante Dulcinea encantada (II, cap. 10). Estampa n. ${ }^{\circ} 9$ en Don Quixote de la Mancha, Londres, Charles Daly, 1842. Imágenes del archivo digital "Iconografía textual del Quijote" <http://cervantes. dh.tamu.edu>, Proyecto Cervantes, Texas A\&M University. 
Sancho que para evitar problemas con su amo le hace ver que tres mozas montadas en sus burras son damas bellas y elegantes. Una apreciación que el propio don Quijote no acierta a visualizar convencido de que lo que tiene delante son en realidad tres labradoras. A pesar de todo, Sancho continúa con la mentira y se arrodilla ante una de ellas afirmando que se trata de la propia Dulcinea del Toboso, convertida en labradora por un encantamiento:

\begin{abstract}
Y, diciendo esto, se adelantó a recebir a las tres aldeanas; y, apeándose del rucio, tuvo del cabestro al jumento de una de las tres labradoras, y, hincando ambas rodillas en el suelo, dijo:

-Reina y princesa y duquesa de la hermosura, vuestra altivez y grandeza sea servida de recebir en su gracia y buen talente al cautivo caballero vuestro, que allí está hecho piedra mármol, todo turbado y sin pulsos de verse ante vuestra magnífica presencia. Yo soy Sancho Panza, su escudero, y él es el asendereado caballero don Quijote de la Mancha, llamado por otro nombre el Caballero de la Triste Figura.

A esta sazón, ya se había puesto don Quijote de hinojos junto a Sancho, y miraba con ojos desencajados y vista turbada a la que Sancho llamaba reina y señora, [y], como no descubría en ella sino una moza aldeana, y no de muy buen rostro, porque era carirredonda y chata, estaba suspenso y admirado, sin osar desplegar los labios. Las labradoras estaban asimismo atónitas, viendo aquellos dos hombres tan diferentes hincados de rodillas, que no dejaban pasar adelante a su compañera...
\end{abstract}

De acuerdo con ello en el dibujo realizado por Gilbert -reproducido fielmente en la viñeta decorativa utilizada en las piezas cerámicas (Fig. 12)- se representa en primer término a Sancho y don Quijote arrodillados ante las tres labradoras a las que han interceptado mientras cabalgaban a lomos de sus respectivas monturas. Complementan la escena unos arbustos dispuestos en el lateral izquierdo y la masa de nubes que soluciona el fondo.

Es en la ejecución del dibujo donde se aprecian las diferencias más notables entre el original y la copia, caracterizándose las estampaciones de las lozas por una mayor simplicidad. Esto se hace más evidente en las piezas de tamaño reducido (pedestales y jícaras) donde también se prescindió, para una mejor adaptación a las pequeñas dimensiones, de una de las mujeres y de elementos accesorios como la lanza y la espada (Fig. 14).

Estampado en los colores azul, castaño y verde, se utilizó además como motivo decorativo principal en dos platos (colección particular), posiblemente de una misma vajilla, rematados con la característica orla isabelina.

\title{
7. Sancho, juez de Barataria. Pleito de la mujer forzada (II, cap. 45)
}

El motivo decorativo principal transferido al plato de Sargadelos estampado en rojo (Fig. 15) está inspirado en el grabado (Fig. 16) destinado a ilustrar, dispuesto entre las páginas 406 y 407, el capítulo 45 del tomo II (edición 


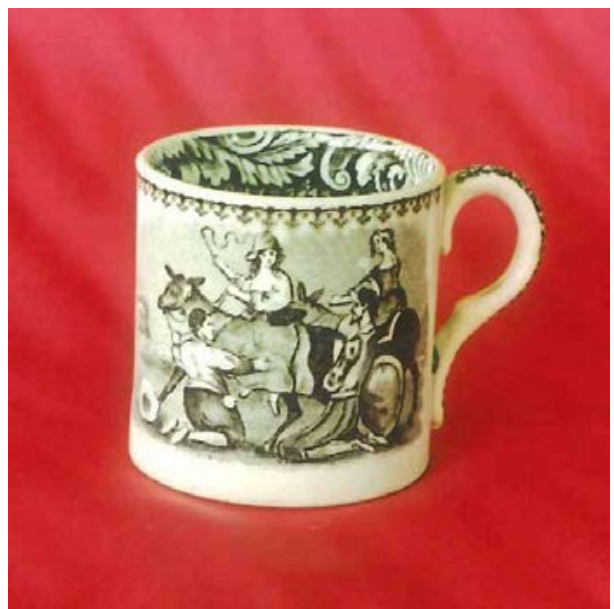

FIgURA 14. Taza para el chocolate en negro con orla isabelina. Colección particular.

londinense del Quijote de 1842) en el que se relata «cómo el gran Sancho Panza tomó la posesión de su ínsula, y del modo que comenzó a gobernar». El dibujo realizado por John Gilbert abierto por un grabador anónimo representa uno de los tres pleitos a los que Sancho tendrá que enfrentarse como gobernador de Barataria: el caso de la mujer forzada.

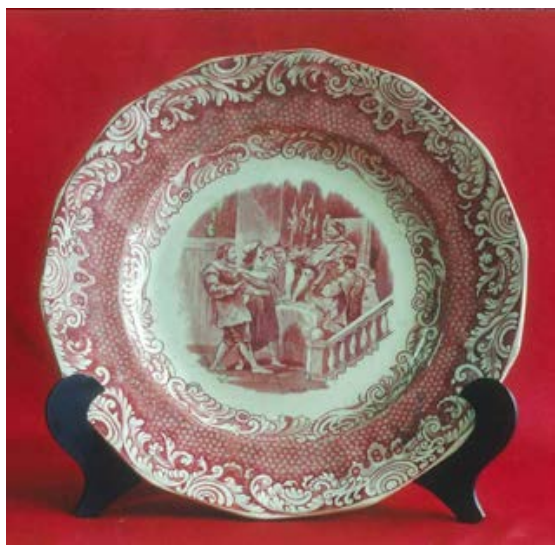

FigURA 15. Plato llano en rojo con orla isabelina. Colección particular.

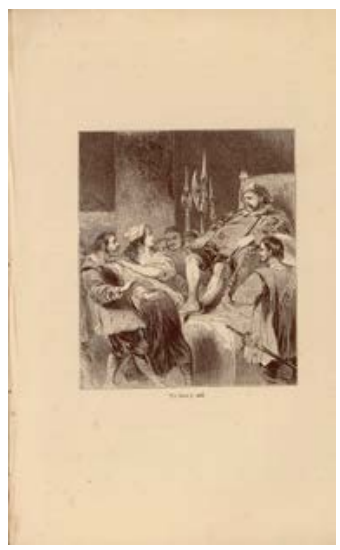

Figura 16. Anónimo por dibujo de John Gilbert. Sancho, juez de Barataria. Pleito de la mujer forzada (II, cap. 45). Estampa n. ${ }^{\circ} 13$ en Don Quixote de la Mancha, Londres, Charles Daly, 1842. Imágenes del archivo digital "Iconografía textual del Quijote" <http://cervantes.dh.tamu. edu>, Proyecto Cervantes, Texas A\&M University. 
Luego, acabado este pleito, entró en el juzgado una mujer asida fuertemente de un hombre vestido de ganadero rico, la cual venía dando grandes voces, diciendo:

-Justicia, señor gobernador, justicia, y si no la hallo en la tierra, la iré a buscar al cielo! Señor gobernador de mi ánima, este mal hombre me ha cogido en la mitad dese campo, y se ha aprovechado de mi cuerpo como si fuera trapo mal lavado, y, ¡desdichada de mí!, me ha llevado lo que yo tenía guardado más de veinte y tres años ha, defendiéndolo de moros y cristianos, de naturales y estranjeros; y yo, siempre dura como un alcornoque, conservándome entera como la salamanquesa en el fuego, o como la lana entre las zarzas, para que este buen hombre llegase ahora con sus manos limpias a manosearme.

De acuerdo con el relato, Sancho -elegantemente vestido acorde con su nuevo cargo- aparece sentado en la silla del juzgado, en una posición más elevada que el resto de los personajes que lo acompañan y actúan como testigos de los hechos. Frente a él, la mujer y el ganadero protagonistas del suceso y ya en un segundo plano, cerrando la composición, una pared con un vano y los remates de tres alabardas que sobresalen entre la multitud y se recortan sobre un fondo oscuro. Un esquema compositivo que se mantiene en el grabado realizado para transferir al plato de Sargadelos en el que sin embargo se han añadido algunos elementos. Es el caso de la escalinata y el correspondiente balaustre del primer término, así como la figura completa de un segundo personaje que en el original se escondía tras el caballero dispuesto a la izquierda de Sancho. Las diferencias en el dibujo siguen siendo notables haciéndose especialmente evidentes en la caracterización de los distintos personajes.

Esta decoración, estampada en los colores azul, rojo y castaño, también se aplicó en piezas de proporciones reducidas, concretamente en una jícara y en una salsera (Fig. 17), ambas en colección particular. Dos ejemplares muy

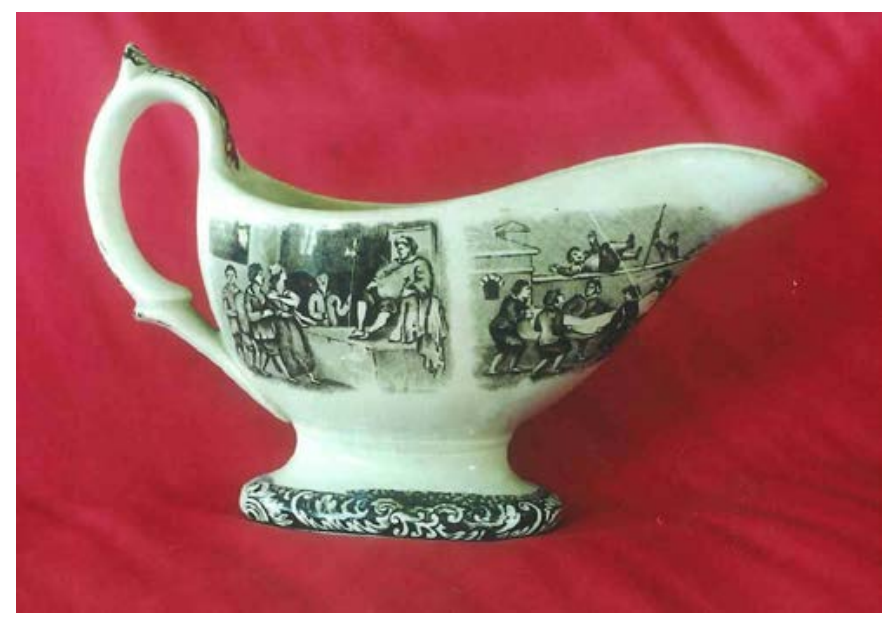

FIGURA 17. Salsera en negro con orla isabelina. Colección particular. 
interesantes donde nos encontramos con una evidente reinterpretación -presumiblemente por necesidades de espacio- del dibujo original de Gilbert.

Se mantiene a Sancho vestido de manera elegante y sentado en el trono y también a los protagonistas del pleito, pero se prescinde de la mayoría del público. Únicamente se ha dejado a un hombre con alabarda a la derecha de Sancho y otro tras el ganadero y la mujer. En el fondo, que sigue siendo oscuro, se mantiene la pared con vano.

\section{El final del Gobierno de Sancho. Sancho se despide (II, cap. 53)}

La viñeta en la que se representa la despedida de Sancho al abandonar su cargo como Gobernador de la Ínsula Barataria se corresponde con el capítulo 53 del tomo II dedicado al «fatigado fin y remate que tuvo el gobierno de Sancho Panza». La estampa (Fig. 18) grabada por Folkard a partir del dibujo de John Gilbert, se dispuso entre las páginas 436 y 437 de la misma edición londinense de Charles Daly para el año 1842. El momento escogido por el dibujante es aquel en el que Sancho, ya sobre su montura, se despide de las personas que lo acompañaron en su breve mandato:

Todos vinieron [en] ello, y le dejaron ir, ofreciéndole primero compañía y todo aquello que quisiese para el regalo de su persona y para la comodidad de su viaje. Sancho dijo que no quería más de un poco de cebada para el rucio y medio queso y medio pan para él; que, pues el camino era tan

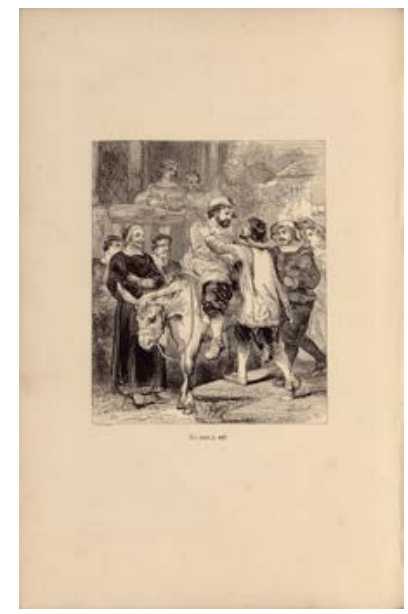

Figura 18. Folkard por dibujo de John Gilbert. El final del Gobierno de Sancho. Sancho se despide (II, cap. 53). Estampa n. ${ }^{\circ} 14$ en Don Quixote de la Mancha, Londres, Charles Daly, 1842. Imágenes del archivo digital "Iconografía textual del Quijote" <http://cervantes.dh.tamu.edu>, Proyecto Cervantes, Texas A\&M University. 
corto, no había menester mayor ni mejor repostería. Abrazáronle todos, y él, llorando, abrazó a todos, y los dejó admirados, así de sus razones como de su determinación tan resoluta y tan discreta.

Esta es la última estampa que encontramos en la serie decorativa del Quijote de Sargadelos inspirada en los dibujos del artista John Gilbert. Al igual que en los ejemplos anteriores, los técnicos de la fábrica luguesa reprodujeron el esquema compositivo de la fuente de inspiración, aunque adaptado a la tipología de las piezas donde el motivo iba a ser transferido. Son tres los ejemplares de los que se tiene constancia: un plato y una sopera estampados en castaño con orla isabelina, ambos en colección particular, y otro plato en violeta con orla corrida de tipo floral (Museo de Pontevedra), para los que se emplearon dos viñetas diferentes.

La primera (Fig. 19) -común para los platos- es la más similar al dibujo original, donde aparece Sancho montado a lomos de su rucio acompañado de varios hombres elegantemente vestidos que observan su marcha o lo despiden afectuosamente. En un segundo plano, dos damas apoyadas sobre un balaustre de un edificio palaciego observando la escena. Se completa con un arbusto y una torre en el fondo. En la segunda (Fig. 20), de proporciones mayores, se mantiene la figura de Sancho, los dos hombres que lo despiden, dos de los que observan de pie al fondo y las damas apoyadas en el balaustre. En contraposición, se añaden nuevas figuras masculinas y se le da un mayor protagonismo al paisaje y la vegetación, consiguiendo abarcar la mayor superficie que es necesario decorar.

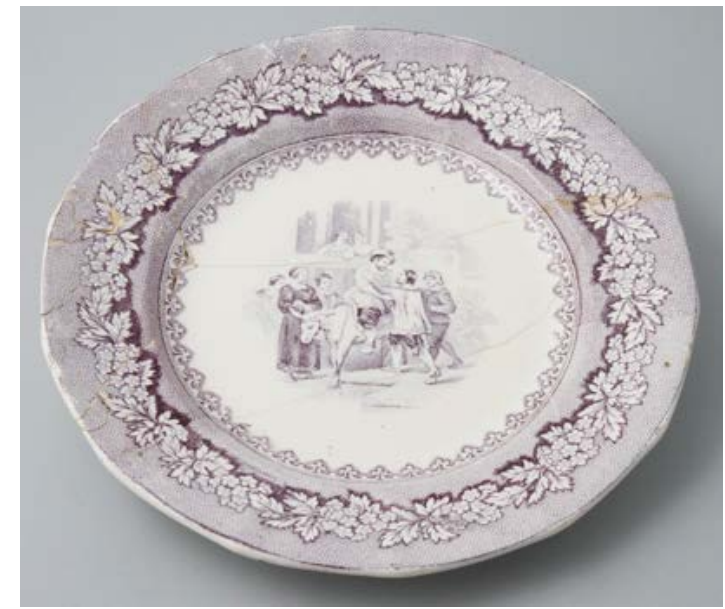

Figura 19. Plato en violeta con orla de hojas dentadas. Museo de Pontevedra (N. ${ }^{\circ}$ Reg. 311). 


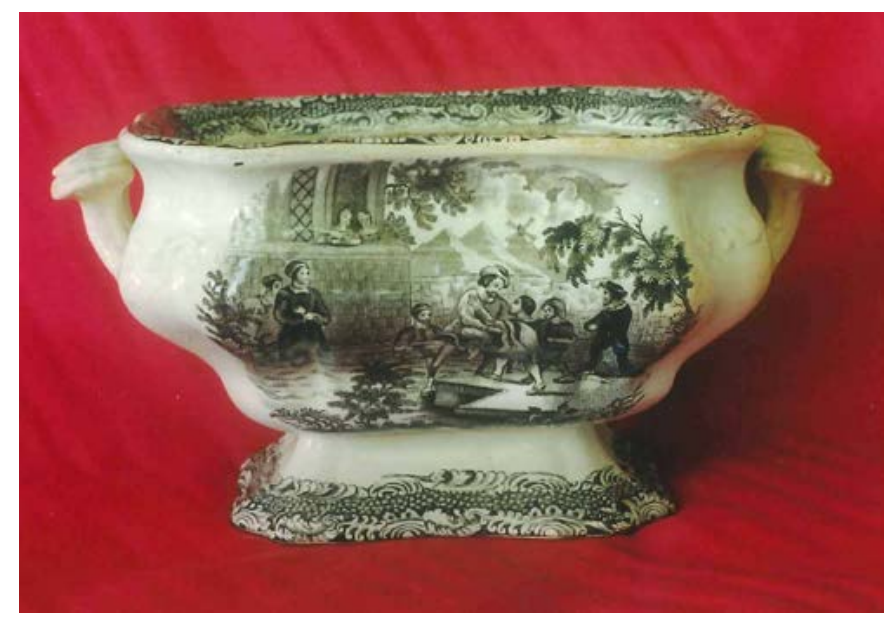

FIGURA 20. Sopera en negro con orla isabelina. Colección particular.

\section{Aventura de los leones. Sancho y el Caballero del Verde Gabán se ponen a cubierto; don Quijote desafía al león (II, cap. 17)}

La viñeta decorativa utilizada como motivo principal para este plato (Fig. 21) representa el episodio del capítulo 17 del tomo II «donde se declaró el último punto y estremo adonde llegó y pudo llegar el inaudito ánimo de don Quijote, con la felicemente acabada aventura de los leones». El momento exacto representado es aquel en el que don Quijote con el escudo embrazado y la espada desenvainada se dispone a atacar a uno de los leones que

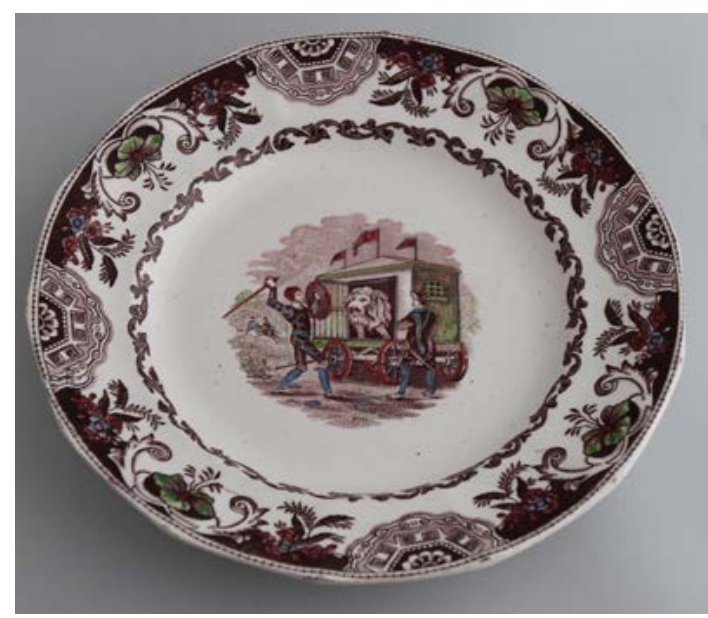

FiguRa 21. Plato llano en negro con orla chinesca iluminado. Museo de Pontevedra (N. ${ }^{\circ}$ Reg. 3153). 
eran transportados en un carro con destino a la Corte. Junto a él el leonero, que observa la escena después de haber abierto la jaula, y al fondo Sancho y el Caballero del Verde Gabán que huyen despavoridos.

\begin{abstract}
A éstas añadió otras razones, con que quitó las esperanzas de que no había de dejar de proseguir su desvariado intento. Quisiera el del Verde Gabán oponérsele, pero viose desigual en las armas, y no le pareció cordura tomarse con un loco, que ya se lo había parecido de todo punto don Quijote; el cual, volviendo a dar priesa al leonero y a reiterar las amenazas, dio ocasión al hidalgo a que picase la yegua, y Sancho al rucio, y el carretero a sus mulas, procurando todos apartarse del carro lo más que pudiesen, antes que los leones se desembanastasen.

Lloraba Sancho la muerte de su señor, que aquella vez sin duda creía que llegaba en las garras de los leones; maldecía su ventura, y llamaba menguada la hora en que le vino al pensamiento volver a servirle; pero no por llorar y lamentarse dejaba de aporrear al rucio para que se alejase del carro. Viendo, pues, el leonero que ya los que iban huyendo estaban bien desviados, tornó a requerir y a intimar a don Quijote lo que ya le había requerido e intimado, el cual respondió que lo oía, y que no se curase de más intimaciones y requirimientos, que todo sería de poco fruto, y que se diese priesa.

En el espacio que tardó el leonero en abrir la jaula primera, estuvo considerando don Quijote si sería bien hacer la batalla antes a pie que a caballo; y, en fin, se determinó de hacerla a pie, temiendo que Rocinante se espantaría con la vista de los leones. Por esto saltó del caballo, arrojó la lanza y embrazó el escudo, y, desenvainando la espada, paso ante paso, con maravilloso denuedo y corazón valiente, se fue a poner delante del carro, encomendándose a Dios de todo corazón, y luego a su señora Dulcinea.
\end{abstract}

La diferencia respecto a las estampas anteriores también utilizadas para la serie decorativa del Quijote en Sargadelos, es que esta no se encontraba entre las ilustraciones realizadas por John Gilbert para la edición londinense de Charles Daly. Tampoco aparece entre las más de doscientas cincuenta imágenes catalogadas que sobre este episodio se registran en las bases de datos destinadas a la recopilación de las distintas ediciones ilustradas de la novela cervantina ${ }^{23}$.

En la búsqueda de similitudes de carácter iconográfico más o menos coetáneas a la fecha en que esta serie decorativa se produjo en la factoría luguesa, encontramos una edición inglesa del año 1837 realizada por Jones \& Co. (Cervantes 1837) con dibujos de Robert Cruikshank, en la que la ilustración correspondiente a este episodio recuerda a la que la Real Fábrica empleó para decorar sus piezas (Fig. 22).

Curiosamente, los dibujos de Cruikshank - publicados por primera vez en 1824 en una edición londinense de la novela cervantina- ya habían servido de inspiración para la decoración de las piezas cerámicas producidas por Brameld \& Co. en Yorkshire. Una coincidencia que podría explicar las simiquijote_banco_imagenes_qbi/> Sobre el proyecto véase González Moreno et al. (2005, 79-104). 


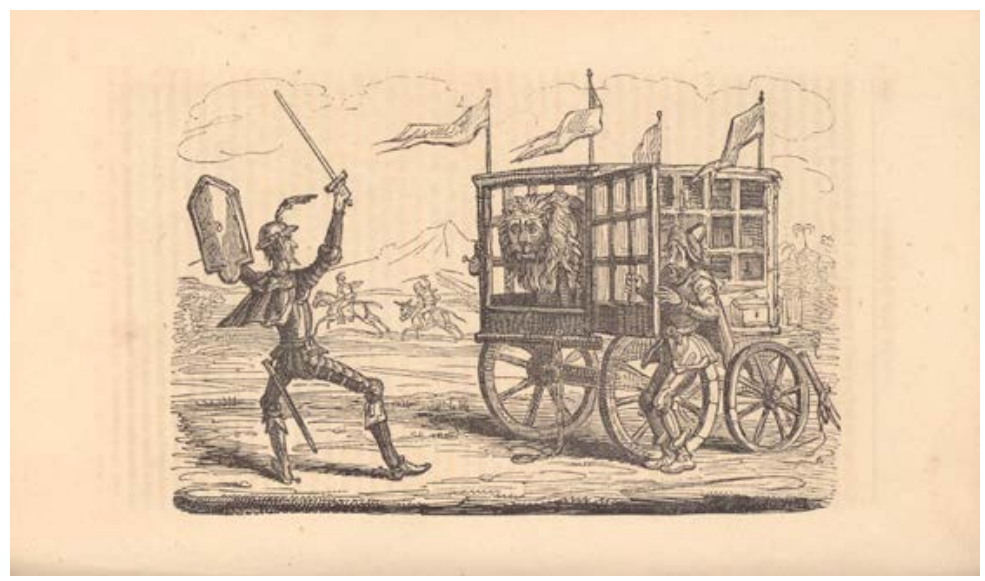

Figura 22. M. U. Sears por dibujo de Robert Cruikshank. Aventura de los leones. Sancho y el Caballero del Verde Gabán se ponen a cubierto; Don Quijote desafía al león (II, cap. 17). Estampa n. ${ }^{\circ} 8$ en The life and exploits of Don Quixote de la Mancha, Londres, Jones \& Co., 1837. Imágenes del archivo digital "Iconografía textual del Quijote" $<$ http://cervantes.dh.tamu.edu>, Proyecto Cervantes, Texas A\&M University.

litudes entre las viñetas de ambas factorías pues quizás, sin tener ninguna prueba que permita confirmarlo con absoluta certeza, podría haber sido alguna de esas piezas y no una edición de la novela, la fuente de inspiración que estos operarios habrían tomado como base para sus creaciones. La posible existencia de algunos ejemplares en Lugo se explicaría por la presencia de un director y técnicos ingleses.

De cualquier modo y de manera independiente a cuál haya sido el punto de partida, es evidente que ambas comparten el esquema compositivo general aunque el tratamiento y disposición de los personajes así como otros elementos constitutivos de la escena son totalmente distintos. El primer elemento discordante es el carruaje que transporta a los leones -rematado únicamente por tres banderolas- que se abre por un lateral y no por la parte trasera como suele ser más habitual. Además, el leonero, generalmente representado realizando esta acción desde la parte superior del mismo o desde uno de los extremos, permanece a un lado observando tranquilamente la escena sin ningún indicio de estar asustado. La estética de don Quijote es similar en ambas ilustraciones; viste armadura y se protege con escudo, de pie, en actitud defensiva dispuesto a enfrentarse al león que asoma desde el carruaje (en este punto también recuerda a la citada edición de 1837) aunque blandiendo la espada hacia atrás, una disposición que no he encontrado en ninguna otra estampa. Las figuras de Sancho y el caballero del Verde Gabán, situadas al fondo huyendo a galope en sus monturas, sí concuerdan con la mayor parte de las ilustraciones examinadas, incluida la correspondiente a la edición de Jones \& Co., al igual que las montañas y la masa nubosa del segundo plano. 
Desde el punto de vista estilístico y a pesar de no tener nada que ver con los grabados realizados a partir de los dibujos de John Gilbert, es evidente que el responsable de la ejecución del grabado que ahora nos ocupa fue el mismo que realizó los anteriores para la serie decorativa del Quijote en Sargadelos. Un técnico de la fábrica luguesa capaz de llevar a cabo una nueva interpretación del episodio -suponemos que tomando como referencia algún modelo que hubiese llegado a sus manos- que se adaptaba de manera adecuada a la tipología de las piezas cerámicas y mantenía el diseño de las viñetas anteriores a pesar de no partir de la misma fuente original.

El porqué de la elección de este pasaje y no otro de los que ilustraban la edición de Charles Daly sigue siendo un aspecto desconocido. Además, y a diferencia de otros modelos de la misma serie, lo encontramos de manera exclusiva en platos. Cuatro de ellos comparten el mismo tipo de orla, la isabelina, aunque en dos tonos distintos: uno en verde y tres en castaño (uno en el Museo de Bellas Artes de La Coruña, N. ${ }^{\circ}$ Inv.: 893). A los anteriores se suman los ejemplares conservados en el Museo de Pontevedra: un plato llano en violeta con la orla de tipo corrido con decoración floral ${ }^{24}$ y el que aquí se reproduce (Fig. 21) de carácter más singular, por estar iluminado, en el que la viñeta principal se combina con una orla chinesca estampada en negro.

\section{Conclusiones}

A pesar de todo lo expuesto, todavía quedan por determinar muchos aspectos relativos a la producción seriada del Quijote en Sargadelos. Al margen de las suposiciones y las preguntas para las que todavía no hay respuesta, el descubrimiento de la fuente iconográfica de referencia sirve para demostrar, una vez más, que Inglaterra era el modelo que seguir de la factoría. La elección de una temática de la categoría del Quijote para la decoración de vajillas y otros elementos propios del ajuar doméstico demuestran, aún sin conocer el motivo que les llevo a hacerlo, las altas pretensiones de la fábrica lucense, pionera al apostar por una temática que aunque sobradamente conocida en España, todavía no había sido introducida en el repertorio decorativo de las principales fábricas de cerámica de la época. Un paso más de una iniciativa empresarial en la que la principal premisa no era otra que ponerse a la altura y poder competir con las mejores de Europa.

\section{BIBLIOGRAFÍA CITADA}

Ardila, J. A. G. 2005. «Traducción y recepción del Quijote en Gran Bretaña (1612-1774)». Anales Cervantinos 37: 253-265. https://doi.org/10.3989/anacervantinos.2005.014.

24. De esta vajilla están localizados cuatro platos, todos en la colección del Museo de Pontevedra. 
Atlee Barber, Edwin. 1899. Anglo-American Pottery. Old English China with american views. A manual for collectors. Indianápolis: s. e. Accesible en: $<\mathrm{https} / / / \mathrm{catalog}$. hathitrust.org/Record/007645615>. Fecha de acceso: 21 de septiembre de 2020.

Bello Piñeiro, Felipe. 1979. Cerámica de Sargadelos. A Coruña: Ediciós do Castro.

Benezit Dictionary of British Graphic Artists and Illustrators. 2012. Nueva York: Oxford University Press, vol. 1.

Carmona Badía, Xoan. 1993. «Sargadelos en la historia de la siderurgia española». Revista de Historia Industrial 3: 26.

Carmona Badía, Xoan. 2009. «Luis de la Riva Barro (1798-1868)». En Empresarios de Galicia, vol. 2, 22-48. Santiago de Compostela: Fundación Caixa Galicia.

Cervantes, Miguel de. 1836-1837. L'ingéniux hidalgo Don Quichotte de la Mancha. París: J. J. Dubochet. Imágenes de las estampas accesibles en: <http://qbi2005.windows. cervantesvirtual.com/wfrmMosaico.aspx $>$ y $<$ http://cervantes.dh.tamu.edu $>$. Fecha de acceso: 21 de septiembre de 2020.

Cervantes, Miguel de. 1837. The life and exploits of Don Quixote de la Mancha. Londres: Jones \& Co. Imágenes de las estampas accesibles en: <http://qbi2005.windows. cervantesvirtual.com/wfrmMosaico.aspx $>$ y $<$ http://cervantes.dh.tamu.edu $>$.

Cervantes, Miguel de. 1842. Don Quixote de la Mancha. Londres: Charles Daly. Imágenes de las estampas accesibles en: <http://qbi2005.windows.cervantesvirtual.com/ wfrmMosaico.aspx $>\mathrm{y}<\mathrm{http}: / /$ cervantes.dh.tamu.edu $>$.

Cervantes, Miguel de. 1842. Don Quixote de la Mancha. Londres: Henry Bohn. Imágenes de las estampas accesibles en: $<$ http://cervantes.dh.tamu.edu $>$.

Close, Anthony. 2005. La concepción romántica del «Quijote». Barcelona: Crítica.

Feit, Alexius. 2017. Iconographie de la faïnce d'Alcora 1727-1798. Castellón de la Plana: e-DitARX Publicaciones Digitales.

Filgueira Valverde, José. 1951. Sargadelos. Santiago de Compostela: Bibliófilos gallegos. Colección Obradoiro, IV.

Fraguas Fernández, Natalia. 2017. Louza da Real Fábrica de Sargadelos. Colección Adriano Marques de Magallanes. Redondela: Concello de Redondela.

Gavin, Lucas. 2003. «Reading Pottery: Literature and Transfer-Printed Pottery in the Early Nineteenth Century». International Journal of Historical Archaeology 7 (2): 127-143.

Givanel i Mas, Joan. 1946. Historia gráfica de Cervantes y del Quijote. Madrid: PlusUltra.

González Moreno, Fernando. 2009. «Don Quijote en los albores del Romanticismo o el prodigio ilustrado de Tony Johannot». En Don Quijote Cosmopolita: nuevos estudios sobre la recepción internacional de la novela cervantina, coord. Hans Christian Hagerdorn, 343-368. Cuenca: Ediciones de la Universidad de Castilla-La Mancha.

Gónzalez Moreno, Fernando y Eduardo Urbina. 2011. «Iconografía textual del Quijote: principales aportaciones para las ediciones del siglo XIX». En Literatura ilustrada decimonónica. 57 perspectivas. Santander: ICEL 19 - PUbliCan: 315-326.

González Moreno, Fernando, Eduardo Urbina, Richard Furuta y Jie Deng. 2005 [2006]. «La colección de Quijotes ilustrados del Proyecto Cervantes: Catálogo de ediciones y archivo digital de imágenes». Cervantes: Bulletin of the Cervantes Society of America 25 (1): 79-104. Accesible en: <https://www.h-net.org/ cervantes/csa/artics05/moreno. pdf $>$. Fecha de acceso: 21 de septiembre de 2020.

Hadegorn, Hans Christian, coord. 2009. Don Quijote cosmopolita. Nuevos estudios sobre la recepción internacional de la novela cervantina. Cuenca: Ediciones de la Universidad de Castilla-La Mancha.

Hyland, Peter. 2005. The Herculaneum pottery. Liverpool: Liverpool's Forgotten GloryNational Museums. 
José i Pitarch, Antoni. 2005. La colección de cerámica de Alcora. The Hispanic Society of America. Castellón: Fundación Blasco de Alagón.

Lenaghan, Patrick, coord. 2003. Imágenes del Quijote. Modelos de representación en las ediciones de los siglos XVII-XIX. Madrid: The Hispanic Society of America, Museo Nacional del Prado, Real Academia de Bellas Artes de San Fernando, Calcografía Nacional.

Lucía Megías, José Manuel. 2005. «Imágenes para un libro universal: Don Quijote de la Mancha (1605-1905)». En Don Quijote en el campus: tesoros complutenses, coord. Marta Torres Santo Domingo, 121-151. Madrid: Biblioteca Histórica "Marqués de Valdecilla".

Lucía Megías, José Manuel. 2006. Leer el Quijote en imágenes: hacia una teoría de los modelos iconográficos. Madrid: Calambur.

Luttikhuizen, Frances. 2005. La primera edición ilustrada del Quijote (Dortrecht, 1657), un libro de emblemas. Accesible en: <https://cvc.cervantes.es/literatura/cervantistas/ coloquios/cl_2005/cl_2005_17.pdf >.

Madoz, Pascual. 1849. «Sargadelos». En Diccionario Geográfico- Estadístico- Histórico de España y sus posesiones de Ultramar XIII, 861-864. Madrid: s. e.

Mañueco Santurtún, Carmen, coord. 2005. La cerámica española y Don Quijote. s. 1.: Empresa Pública Don Quijote de la Mancha.

Meijide Pardo, Antonio. 1979. «Documentos para la historia de las Reales Fábricas de Sargadelos». En Cuadernos del seminario de estudios cerámicos de Sargadelos 29. La Coruña: Ediciós do Castro.

Neira de Mosquera, Antonio. 1851. «La fábrica de Sargadelos». Semanario Pintoresco Español, 21 de diciembre: 405-406.

Price, E. Stanley. 1948. John Sadler. A Liverpool Pottery Printer. Cheshire: Self-Published - West Kirby.

Quiroga Figueroa, María. 2003. A louza de Sargadelos. Lugo: Diputación Provincial.

Rial López, Pedro. 2005. «El Quijote en Sargadelos». En La cerámica española y Don Quijote, coord. Carmen Mañueco Santurtún, 164-177. Madrid: Empresa Pública Don Quijote de la Mancha.

Suñe Benages, Juan y Juan Suñe Fonbuena. 1917. Bibliografia crítica de ediciones del Quijote impresas desde 1605 hasta 1917. Barcelona: Editorial Perelló S. A.

Torres Santo Domingo, Marta, coord. 2005. Don Quijote en el campus: tesoros complutenses. Madrid: Biblioteca Histórica "Marqués de Valdecilla".

Recibido: 26 de junio de 2019

Aceptado: 14 de julio de 2020 